\title{
Oceanic migration behaviour of tropical Pacific eels from Vanuatu
}

\author{
Robert Schabetsberger ${ }^{1, *}$, Finn Økland ${ }^{2}$, Kim Aarestrup ${ }^{3}$, Donna Kalfatak ${ }^{4}$, Ursula \\ Sichrowsky ${ }^{5}$, Meelis Tambets ${ }^{6}$, Giorgio Dall'Olmo ${ }^{7}$, Roland Kaiser ${ }^{1}$, Peter I. Miller ${ }^{7}$ \\ ${ }^{1}$ Department of Cell Biology, University of Salzburg, 5020 Salzburg, Austria \\ ${ }^{2}$ The Norwegian Institute of Nature Research, 7047 Trondheim, Norway \\ ${ }^{3}$ Denmark Technical University, 8600 Silkeborg, Denmark \\ ${ }^{4}$ Department of Environmental Protection and Conservation, Port Vila, Vanuatu \\ ${ }^{5}$ Department of Limnology, University of Innsbruck, 6020 Innsbruck, Austria \\ ${ }^{6}$ Estonian Marine Institute, University of Tartu, Mäealuse 14, 12618 Tallinn, Estonia \\ ${ }^{7}$ Plymouth Marine Laboratory, Plymouth PL1 3DH, UK
}

\begin{abstract}
Information on oceanic migrations and spawning areas of tropical Pacific freshwater eels (genus Anguilla) is very limited. Lake Letas and its single outflowing river, Mbe Solomul on Gaua Island, Vanuatu, were surveyed for large migrating individuals. Twenty-four Anguilla marmorata $(87$ to $142 \mathrm{~cm}), 39$ A. megastoma (50 to $131 \mathrm{~cm})$, and 3 A. obscura $(119$ to $126 \mathrm{~cm}$ ) were caught. Seven individuals were tagged with pop-up satellite transmitters and released offshore. One A. marmorata migrated $843 \mathrm{~km}$ towards the South Equatorial Current. The tag surfaced only $330 \mathrm{~km}$ from the point where the smallest leptocephalus has been captured so far. Tags on $A$. megastoma and A. obscura popped up within the archipelago. All 3 species exhibited pronounced diel vertical migrations. Eels descended from around $200 \mathrm{~m}$ nighttime depth, to 320 (A. obscura), 650 (A. marmorata), and $750 \mathrm{~m}$ (A. megastoma) during the day. A clear impact of the lunar cycle on the upper limit of migration depths was found in A. marmorata (full moon: $230 \mathrm{~m}$, new moon: $170 \mathrm{~m}$ ). These behaviours may be explained as a trade-off between predator avoidance and the necessity to maintain a sufficiently high metabolism for migration.
\end{abstract}

KEY WORDS: Anguilla $\cdot$ Catadromy $\cdot$ Diel vertical migration $\cdot$ Predator avoidance $\cdot$ Satellite telemetry Resale or republication not permitted without written consent of the publisher

\section{INTRODUCTION}

The spawning areas of catadromous eels (genus Anguilla) are only known for some of the 19 species and subspecies, based on the distribution of very young larvae (Schmidt 1922, 1925, Aoyama et al. 2003, Tsukamoto et al. 2011). Temperate European eels Anguilla anguilla cover the longest distances and migrate $>5000 \mathrm{~km}$ across the Atlantic to spawn in the Sargasso Sea. Besides bluefin tuna Thunnus thunnus $(12000 \mathrm{~km})$ and white shark Carcharodon carcharias $(3800 \mathrm{~km})$, these are among the longest migrations that have ever been documented in fish (Alerstam et al. 2003).
Spawning adults and newly hatched leptocephali of Japanese Anguilla japonica and giant mottled eel A. marmorata have been collected sympatrically. Spawning occurs during new moon periods just below the thermocline south of a salinity front along the West Mariana ridge (Chow et al. 2009, Tsukamoto et al. 2011), showing that different species could use the same oceanographic features for reproduction (Kuroki et al. 2009). Oceanographic fronts seem to be key features of eel spawning areas (Munk et al. 2010) and are therefore primary targets for the search for small eel larvae.

Besides studying the distribution of leptocephali, the idea of tagging migrating silver eels with trans- 
mitters to follow their migration has already been pursued since the 1970s (Tesch 1974). In the past decade pop-up satellite archival transmitters (PSAT) were developed and successfully mounted on migrating individuals (Jellyman \& Tsukamoto 2002). In the new generation of smaller tags, temperature, depth, and light are stored and transmitted to Argos satellites once the transmitters have surfaced after a pre-programmed time. However, they are relatively large and have been shown to have negative effects on swimming performance in $1 \mathrm{~kg}$ European eels (Burgerhout et al. 2011, Methling et al. 2011).

Distinct diel vertical migrations (DVM) were observed in temperate New Zealand Anguilla dieffenbachii (Jellyman \& Tsukamoto 2005, 2010), European A. anguilla (Aarestrup et al. 2009), and Japanese A. japonica (Manabe et al. 2011) eels. Varying between both individuals and species, they descend from shallower night-time depths (100 to $500 \mathrm{~m}$ ) into the mesopelagic zone during the day (500 to $1000 \mathrm{~m}$ ).

Behavioural thermoregulation, predator avoidance, the need to obtain cues for orientation, movement to specific depths to obtain current-assisted transport, search for mates, or some combination of these have been hypothesized as selective forces for distinct DVMs (Jellyman \& Tsukamoto 2005, Righton et al. 2012). Migrating at minimal light levels reduces the risk of predation from oceanic predators (sharks, swordfish, tunas). The ascent into warmer water may allow the maintenance of high metabolism and swimming activity, whereas the descent into deeper water could permit the eels to delay their gonadal development until reaching the spawning areas (Aarestrup et al. 2009, Jellyman \& Tsukamoto 2010). However, the behaviour must result in a net benefit compared to staying at constant depth to offset the energetic costs involved.

Study of the oceanic migrations of eels has become vital to understanding what has caused the steep decline in the stocks of temperate eels (Aoyama 2009, Tsukamoto 2009). It is still a matter of discussion whether the driving forces are anthropogenic impacts in fresh or brackish water (e.g. recreational and commercial fishing, barriers to passage, habitat alterations, pollution, introduced parasites; Van Ginneken \& Maes 2005), or changes in oceanic conditions reducing survival of leptocephali (Knights 2003, Friedland et al. 2007). Infections with introduced parasites (Székely et al. 2009) and viruses (Haenen et al. 2009), contamination with polychlorinated biphenyls (PCBs; Van Ginneken et al. 2009), and diminished fat stores (Van den Thillart et al. 2009) due to low trophic quality within degraded freshwater ecosystems re- duce the swimming fitness of silver eels and may be the ultimate reason for a large proportion not reaching the spawning areas. Tropical eel stocks on remote and undeveloped islands are not exposed to the majority of these stressors. Tracking success might be higher and could provide new insight into the migratory behaviour of tropical eels, their full range of DVM, and swimming speeds.

Little is known about the biology of eel species occurring in the tropical western South Pacific (giant mottled eel Anguilla marmorata, Pacific long-finned eel A. megastoma, Pacific short-finned eel A. obscura, speckled long-finned eel $A$. reinhardtii). Some eel populations have been studied scientifically (Marquet \& Lamarque 1986, Jellyman 1991, Marquet \& Galzin 1991, Marquet 1996), but their biology (densities, silvering, migration behaviour, recruitment) remains poorly understood (Aoyama 2009, Tsukamoto 2009). As a key difference to temperate eels, tropical species seem to have shorter migrations and a more extensive spawning season (Miller et al. 2002). It is assumed that western South Pacific eels spawn somewhere within the South Equatorial Current (SEC; Jellyman 2003). The few leptocephali collected so far support this hypothesis (Kuroki et al. 2008).

In this study we surveyed Lake Letas and its outflow on the Gaua Island, Vanuatu, for large and migrating Pacific eels (Anguilla marmorata, A. megastoma, A. obscura), in order to follow eel migration to their unknown spawning areas with PSATs. We tested the hypotheses that tropical eels exhibit DVMs similar to temperate species and migrate towards the SEC. The island was chosen for a number of reasons. (1) The former 3 species occur sympatrically here (Keith et al. 2011). (2) It is in the centre of the area where leptocephali of tropical eel species have been found (Kuroki et al. 2008). (3) Lake Letas is the largest tropical volcanic lake in the western South Pacific and, according to a survey of lakes (Schabetsberger et al. 2009), the eel populations must be among the largest in the entire South Pacific. (4) All eels emigrating from Lake Letas are funnelled down through 1 river. Hence, this location is a good place to study eel migration using a comparative approach among species.

\section{MATERIALS AND METHODS}

\section{Study area}

Gaua Island (Banks Group, Vanuatu) is the emerged top of a $3000 \mathrm{~m}$ high and $40 \mathrm{~km}$ wide stratovolcano. The symmetrical cone of approx. $25 \mathrm{~km}$ 
diameter is truncated between 500 and $690 \mathrm{~m}$ altitude by an $8.5 \times 6 \mathrm{~km}$ central caldera (Fig. 1A). Its active volcano Mt. Garet (979 m a.s.l., $350 \mathrm{~m}$ high, base $3 \mathrm{~km}$ ) towers over the crescent-shaped Lake Letas (100 m depth, $7 \times 2 \mathrm{~km}, 418 \mathrm{~m}$ a.s.l.), which is constantly fertilized by the inflow of nutrient-rich, warm volcanic springs. Oxygen is available all the way to the deepest point $(100 \mathrm{~m})$, and abundant invertebrate life provides rich food resources (Schabetsberger unpubl. obs.). Migrating eels leave the lake through the outflowing Mbe Solomul River. It falls over a $120 \mathrm{~m}$ high cascade (Siri Falls) and bifurcates into 1 larger $\left(18 \mathrm{~m}^{3} \mathrm{~s}^{-1}\right)$ and 2 smaller rivers $(0.9$ and $6.1 \mathrm{~m}^{3} \mathrm{~s}^{-1}$ ) before entering the sea. Flow rates increase significantly during heavy rain. According to the experience of local fishermen, eels predominantly leave Lake Letas during heavy rains and north-westerly winds between January and March, but may emigrate throughout the year. A tropical depression hitting the island on 24 January 2012 yielded silvering eels in the lower stretches of the flooding river several days later.

\section{Fishing and tagging}

Between 17 January and 2 February 2012, Lake Letas and its outflow were surveyed for silver eels by electrofishing, hooks, hook and line, and fyke nets in collaboration with fishermen from Gaua. The research team (R. Schabetsberger, F. Økland D. Kalfatak, U. Sichrowsky, M. Tambets) then anaesthetized, photographed, and measured the fish before they were either released (17 including tagged fish) or sacrificed (49) and given to local families.

Total length, distance from lower jaw to anus, to dorsal fin, and to gill opening, as well as length of mouth and length of pectoral fin were measured with a measuring tape to the nearest mm. Horizontal and vertical eye diameter was measured to the nearest $0.1 \mathrm{~mm}$ with ruler callipers. Weight measurements were taken on a Voltcraft HS-30 balance to the nearest $10 \mathrm{~g}$. All eel species were determined through analysis of body proportions and dentition of the upper jaw (Ege 1939, p. 248-251). Colouration of the total body and the relative size of the eyes (Okamura et al. 2007) were used to classify silver eels. The stomachs of 7 Anguilla marmorata (4 yellow/3 silver) and 13 A. megastoma (9/4) were opened and checked for contents.

During the last $3 \mathrm{~d}$ of fishing operations, 7 eels with a silvery appearance (1 Anguilla marmorata, 4 A. megastoma, 2 A. obscura; Table 1) were caught for tagging by local fishermen at the banks of the main river below Siri Falls, where fish are frequently found in shallow water after plummeting over the cascade. The single $A$. marmorata was caught near the mouth of the river. The tags were put on 3 different species,
A

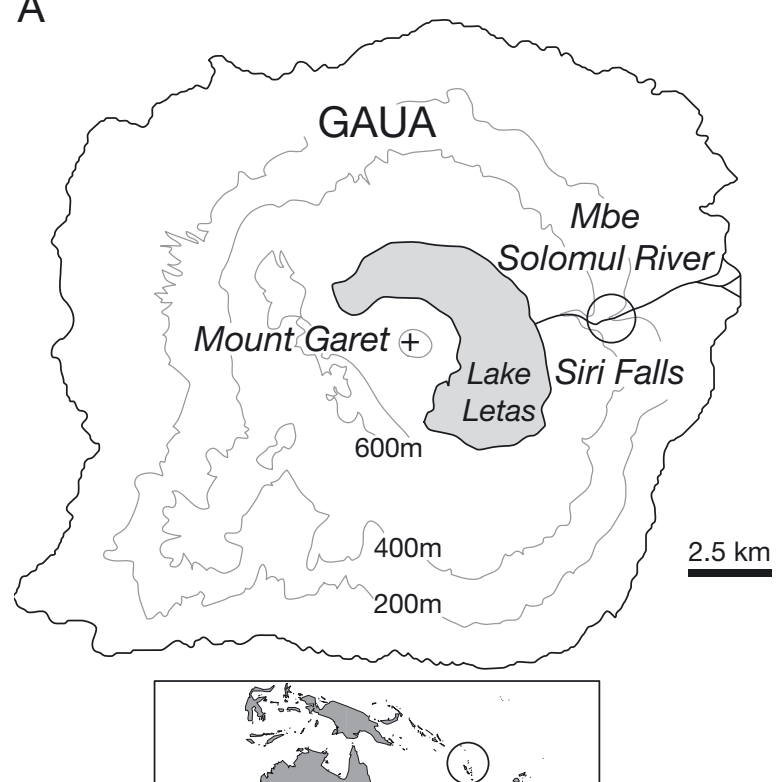

B

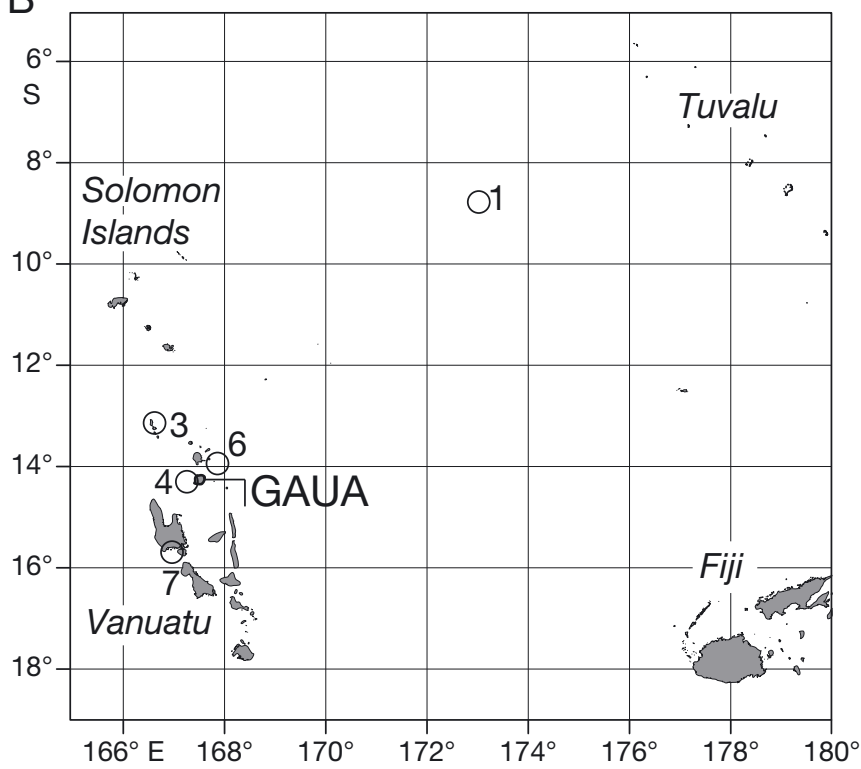

Fig. 1. Anguilla marmorata, A. megastoma, A. obscura. (A) Map of Gaua Island in the Banks Group, Vanuatu, and its geographic position in the South Pacific. (B) Pop-up locations of satellite tags attached to 3 species of tropical eels (numbers corresponding to Table 1) 
Table 1. Anguilla marmorata, A. megastoma, A. obscura. Fish number, species, total length (TL), body weight (BW), and pop-up day (Surface) and position of tags put on 7 eels from Gaua Island on 2 February 2012. Asterisks indicate A. megastoma tagged with Mini-Pats

\begin{tabular}{|c|c|c|c|c|c|}
\hline $\begin{array}{l}\text { Num- } \\
\text { ber }\end{array}$ & Species & $\begin{array}{c}\mathrm{TL} \\
(\mathrm{cm})\end{array}$ & $\begin{array}{l}\text { BW } \\
\text { (kg) }\end{array}$ & Surface & Pop-up position \\
\hline 1 & A. marmorata & 129.6 & 5.7 & 2 May 2012 & $8.770^{\circ} \mathrm{S}, 173.016^{\circ} \mathrm{E}$ \\
\hline 2 & A. megastoma* & 111.0 & 4.1 & Lost & \\
\hline 3 & A. megastoma* & 117.0 & 4.9 & 27 Apr 2012 & $13.160^{\circ} \mathrm{S}, 166.587^{\circ} \mathrm{E}$ \\
\hline 4 & A. megastoma & 115.5 & 4.1 & 8 Mar 2012 & $14.290^{\circ} \mathrm{S}, 167.263^{\circ} \mathrm{E}$ \\
\hline 5 & A. megastoma & 109.5 & 3.3 & Lost & \\
\hline 6 & A. obscura & 126.0 & 4.6 & 25 Apr 2012 & $13.937^{\circ} \mathrm{S}, 167.884^{\circ} \mathrm{E}$ \\
\hline 7 & A. obscura & 117.0 & 3.7 & 9 Feb 2012 & $15.717^{\circ} \mathrm{S}, 166.999^{\circ} \mathrm{E}$ \\
\hline
\end{tabular}

because we were unable to catch enough silver eels of the original target species A. megastoma. Due to the strong current that prevented the use of other fishing gear, the animals were pulled out from littoral hiding places with metal hooks mounted on wooden poles and pushed into hand-nets, resulting in minor skin lesions $(\mathrm{ca} .1 \mathrm{~cm})$ behind the anus. The small wounds were not treated with antibiotics, nor were they sutured to avoid the inclusion of anaerobic germs (F. Økland pers. obs.).

The eels were transported in nets for 0.5 to $2 \mathrm{~h}$, placed into a $2 \mathrm{~m}$ long and $1 \mathrm{~m}$ wide keep-net (ca. $2 \mathrm{~mm}$ mesh size) submerged into the pure freshwater current of the northernmost fork of Mbe Solomul River ca. $100 \mathrm{~m}$ from its mouth. Between 14:00 and 17:00 h on 2 February, fish were removed one by one and immersed in a bath containing 8 to $10 \mu \mathrm{g} \mathrm{l} \mathrm{l}^{-1}$ Metomidate (Marinil ${ }^{\mathrm{TM}}$, Wildlife Labs) until unconscious.

After measuring, 2 types of satellite pop-up transmitters were deployed. Two eels were tagged with Mini-Pats (Wildlife Computers, Type 1; Table 1), and the remaining 5 individuals, with $\mathrm{X}$-tags (Microwave Telemetry, Type 2; Table 1 ). Type 1 tags were provided for free by the manufacturer, and Type 2 tags were refurbished with new batteries after use in a previous project. The Type 1 tag is $11.5 \mathrm{~cm}$ long (excluding antenna), $40 \mathrm{~mm}$ wide and weighs $53 \mathrm{~g}$ in air. The Type $2 \mathrm{tag}$ measures $12 \mathrm{~cm}$ in length, is $32 \mathrm{~mm}$ wide, and weighs $42 \mathrm{~g}$.

Tags were attached externally using a bridle. Three hypodermic needles (20 gauge) were pushed subcutaneously through the dorsal skin for the length of approximately $3 \mathrm{~cm}$, and a $0.8 \mathrm{~mm}$ surgical steel wire was then fed through the bore of the needles before they were removed. The ends of the wire were then twisted, and the transmitter was attached with a $3 \mathrm{~mm}$ nylon braid laced through the metal loops. This secured and held the transmitter, which then floated approximately $3 \mathrm{~cm}$ above the back of the eel. The tags were attached just anterior to the start of the dorsal fin in Anguilla marmorata and $A$. megastoma and approximately halfway between the snout and the start of the dorsal fin in A. obscura. The procedure was rapid and generally took $<2 \mathrm{~min}$ to complete. Eels recovered from anaesthesia within $<5$ min.

Subsequently, the eels were placed into 2 aluminium boxes $(70 \times 50 \times$ $40 \mathrm{~cm}$ ) filled with freshwater that was frequently changed to ensure high oxygen concentrations. To avoid predation by sharks within the reef, the animals were transported $3.8 \mathrm{~km}$ offshore east of Gaua. While going out to sea, saltwater was gradually added to the tanks until freshwater was fully replaced. Eels were tagged and released in subsets of 2 and 5 fish ensuring that the total time between anaesthesia and release did not exceed $2 \mathrm{~h}$.

The tags are slightly buoyant. Sensors in the tag collect and archive data on pressure (depth), water temperature, and light. However, low light levels during deployment prevented use of the latter parameter. The tags were programmed to transmit depth readings for $2 \mathrm{~min}$ (Type 1) or $15 \mathrm{~min}$ (Type 2) intervals, and temperature readings, for $6 \mathrm{~h}$ (Type 1) or 15 min (Type 2) intervals. Due to restricted battery life and size limitations of transmitted data packets, temperature and depth readings are compressed before they are transmitted to Argos satellites. If a fish dives $>166.8 \mathrm{~m}$ or ascends $>172.1 \mathrm{~m}$ in a $1 \mathrm{~h}$ period, then the minimum and maximum depth delta limits are transmitted. The same holds true if the temperature readings differ beyond a predetermined but variable threshold. Delta-limited depth and temperature records may not capture the actual extent of steep vertical movements and rapid temperature variations.

The tags were pre-programmed to surface after 3 mo assuming that the eels spawn north of Fiji and migrate with a speed of approximately $15 \mathrm{~km} \mathrm{~d}^{-1}$, based on the discovery of leptocephali east of Gaua (Kuroki et al. 2008) and the migration speed of similarsized Anguilla dieffenbachii (Jellyman \& Tsukamoto 2002). In case of premature death of the host or detachment of the tag, the transmitters were programmed to initiate a fail safe release mechanism, ascend to the surface, and transmit data. A depth reading deeper than $2100 \mathrm{~m}$ (pressure transducer sensor range exceeded) or $4 \mathrm{~d}$ of equal depth readings $( \pm 10 \mathrm{~m})$ would initiate this mechanism. 


\section{Oceanographic conditions}

Water clarity, surface currents and salinity, frequency of oceanographic fronts, and bathymetry were analysed between 5 and $8^{\circ} \mathrm{S}$ and 165 to $180^{\circ} \mathrm{E}$. The vertical diffuse attenuation coefficient $K_{\mathrm{d}}$ at $490 \mathrm{~nm}$ indicates how visible light in the blue-green region of the spectrum is attenuated by the water column and was estimated from MODIS AQUA data (Moderate Resolution Imaging Spectroradiometer, modis.gsfc.nasa.gov) at $9 \mathrm{~km}$ spatial resolution. Surface salinity was obtained from SMOS (European Space Agency's Soil Moisture and Ocean Salinity, www.esa.int). Data on surface currents were downloaded from OSCAR (Ocean Surface Currents Analysis Realtime, www.oscar.noaa.gov). Eight-day composite front maps (Miller 2009) were derived from daily merged microwave and infrared sea surface temperature data from 2006 to 2011 (February to May) provided by RSS (Remote Sensing Systems, www.ssmi.com) and then aggregated to indicate the regions where strong thermal fronts were most frequently observed. $K_{\mathrm{d}}$, surface currents, and salinity were temporal averages from February to May 2012. The ocean bathymetry was obtained from GEBCO (General Bathymetric Chart of the Oceans, www. gebco.net). All websites were accessed between July and December 2012.

Simple theoretical drift trajectories of larvae were derived using a deterministic geometric model based on surface current direction and velocity. We simulated backward drift trajectories for 100 randomly placed starting points in the 3 grid cells adjoining Gaua in its north, north-east, and east. Calculations were performed on an $18 \mathrm{yr}$ mean current composite (OSCAR, 1993 to 2011) and on the original $1^{\circ}$ cell grid resolution.

Vertical profiles of light levels along the assumed straight migration path of Anguilla marmorata were calculated under the following assumptions. Throughout $24 \mathrm{~h}$ sunlight and moonlight are attenuated to the same extent by the earth's atmosphere. $K_{\mathrm{d}}$ is constant with depth and time of day but varies along the assumed migration trajectory following the satellite-based estimates. Irradiance at $490 \mathrm{~nm}$ of the full moon $\left(E_{\mathrm{m} i}\right.$ Kieffer \& Stone 2005) and the sun $\left(E_{\mathrm{s}}\right.$ Gregg \& Carder 1990) just below the water surface decrease with depth according to the Lambert-Beer law:

$$
E_{i}(z)=E_{i}(z=0) \mathrm{e}^{-\left(K_{\mathrm{d}} z\right)}
$$

where $z$ is the depth in metres below the surface and $E_{i}$ stands for $E_{\mathrm{m}}$ or $E_{\mathrm{s}}$. The influence of a vertically structured $K_{\mathrm{d}}$ profile related to a deep-chlorophyll maximum was also investigated, but $E_{i}$ varied only marginally.

\section{RESULTS}

\section{Species composition}

A total of 24 Anguilla marmorata (10 lake, 14 river), 39 A. megastoma (24 lake, 15 river), and 3 A. obscura (river) were caught. Total lengths ranged from 86.8 to $142.0 \mathrm{~cm}$ in A. marmorata, 49.8 to $130.7 \mathrm{~cm}$ in $A$. megastoma, and 119.4 to $126.0 \mathrm{~cm}$ in A. obscura. A third of the total catch (8 A. marmorata [101 to $142 \mathrm{~cm}$ ], 11 A. megastoma [93 to $123 \mathrm{~cm}$ ], and the 3 A. obscura; $91 \%$ caught in river) were eels with signs of silvering exhibiting a significantly larger eye index compared to yellow eels (A. marmorata yellow/silver eels, 10.3/ 13.0; A. megastoma, 7.5/10.7; $t$-test, $\mathrm{p}<0.01$ ). The stomachs of silver eels from the river were all empty, whereas in yellow eels from both habitats $75 \%$ of $A$. marmorata and $89 \%$ of A. megastoma contained food.

\section{Oceanic migration}

Five of the 7 tags deployed provided data, and 2 were lost for unknown reasons. Only 1 eel (Anguilla marmorata) migrated towards the SEC and its tag surfaced exactly after the programmed $3 \mathrm{mo}$, whereas the others surfaced within the archipelago of Vanuatu prior to the programmed release date (Fig. 1B).

\section{Anguilla marmorata, Eel 1 (Table 1)}

Right after release, the eel started DVM (Fig. 2A). Within $4 \mathrm{~d}$ it gradually increased migration depth and then exhibited a constant DVM behaviour, ascending from median depth of $631 \mathrm{~m}$ (range: 543 to $656 \mathrm{~m}$ ) during the day (06:00 to $17: 00 \mathrm{~h}$ ) to $175 \mathrm{~m}$ (132 to $269 \mathrm{~m}$ ) during the night (19:00 to 04:00 h). Concurrently, temperatures oscillated between $6.0^{\circ} \mathrm{C}\left(5.5\right.$ to $\left.6.5^{\circ} \mathrm{C}\right)$ and $23.0^{\circ} \mathrm{C}\left(14.2\right.$ to $\left.25.8^{\circ} \mathrm{C}\right)$. Minimum temperature recorded at maximum depth was $5.0^{\circ} \mathrm{C}$. As in all other tags deployed, a delay in temperature readings was observed during steep vertical movements (Fig. 2). The fish ascended and descended within approximately $1 \mathrm{~h}$ during dusk and dawn, respectively (Fig. 3).

A clear impact of the lunar cycle on the upper limit of migration depths was found. During full moon, the eel's median night-time migration depths ranged 

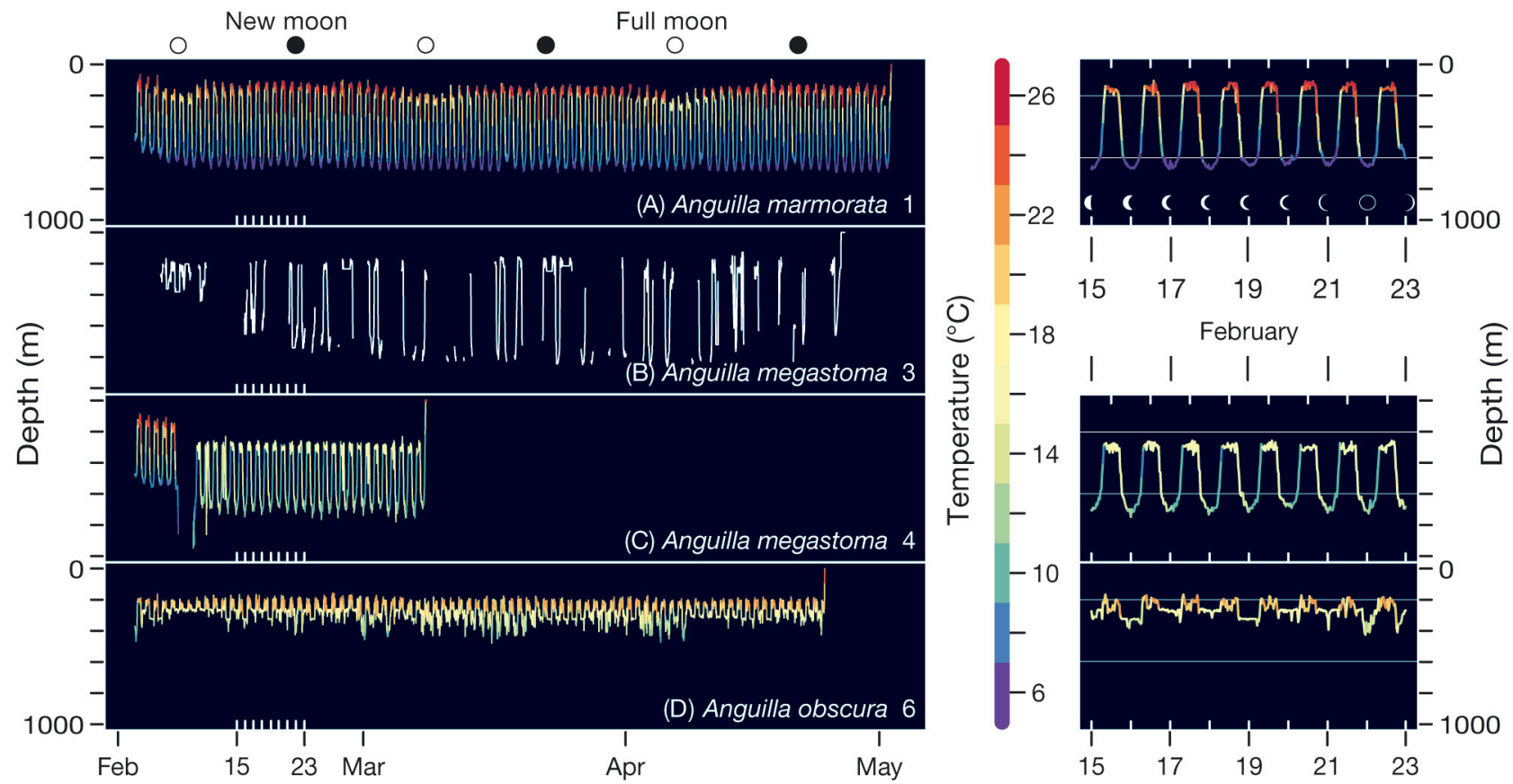

Fig. 2. Anguilla marmorata (A), A. megastoma (B,C), A. obscura (D). Vertical migrations of tagged eels for the entire period (left) and the week 15 to 23 February (right; Eel 3 omitted, horizontal white lines indicate 200 and $600 \mathrm{~m}$ depths)

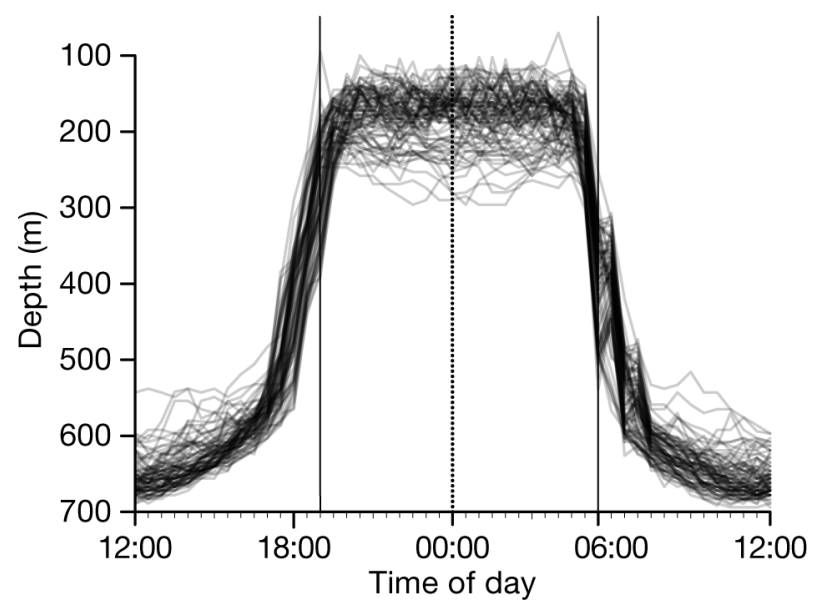

Fig. 3. Anguilla marmorata. Diel vertical migration trajectories over 3 mo. Solid vertical lines correspond to sunset and sunrise; the dotted line indicates midnight. Apparent stepwise downward movements resulted from diving velocity exceeding the resolution of delta-delimited depth readings

from 230 to $269 \mathrm{~m}$, while it ascended to 132 to $190 \mathrm{~m}$ during new moon, seeking greater depth in water of higher clarity (Fig. 4). Modelling light conditions along a straight line from release to pop-up location suggests that the eel was exposed to higher irradiance during the day (Fig. 5A) than it was trying to avoid during full moon (Fig. 5B). The eel also reached maximum depth around local noon and, thus, maximum surface irradiance.
The fish migrated $843 \mathrm{~km}$ towards the NE, with an average speed over ground of $9.4 \mathrm{~km} \mathrm{~d}^{-1}$ through water of comparatively high clarity (Fig. 6A). It first encountered a weak south-eastward surface current and eventually reached the westward SEC flowing at approximately $0.1 \mathrm{~m} \mathrm{~s}^{-1}$ (Fig. 6B). The tag surfaced in water of comparatively low salinity (Fig. 6C), with little thermal frontal activity (Fig. 6D), over a depth exceeding $5000 \mathrm{~m}$ (Fig. 6E), and $330 \mathrm{~km}$ from the point where the smallest leptocephalus larva has been found to date (Fig. 6F). Drift simulations show that during average flow regimes observed during the past $18 \mathrm{yr}$, leptocephali from the pop-up location can potentially reach Gaua within $189 \pm 34$ d (mean \pm $\mathrm{SD})$.

\section{Anguilla megastoma, Eel 3}

Similar to A. marmorata, this specimen started DVM after release and gradually descended to a greater depth for approximately 3 wk (Fig. 2B). From 21 February until 12 April, median depth was $743 \mathrm{~m}$ (215 to $829 \mathrm{~m}$ ) during the day and $186 \mathrm{~m}$ (168 to $341 \mathrm{~m})$ during the night, corresponding to $5.6^{\circ} \mathrm{C}(5.2$ to $7.8^{\circ} \mathrm{C}$ ) and $22.9^{\circ} \mathrm{C}\left(19.8\right.$ to $\left.24.4^{\circ} \mathrm{C}\right)$, respectively. Temperature records received were too scarce for continuous readings, because the tag was washed ashore on Hiw Island in the Torres Group (Vanuatu), 


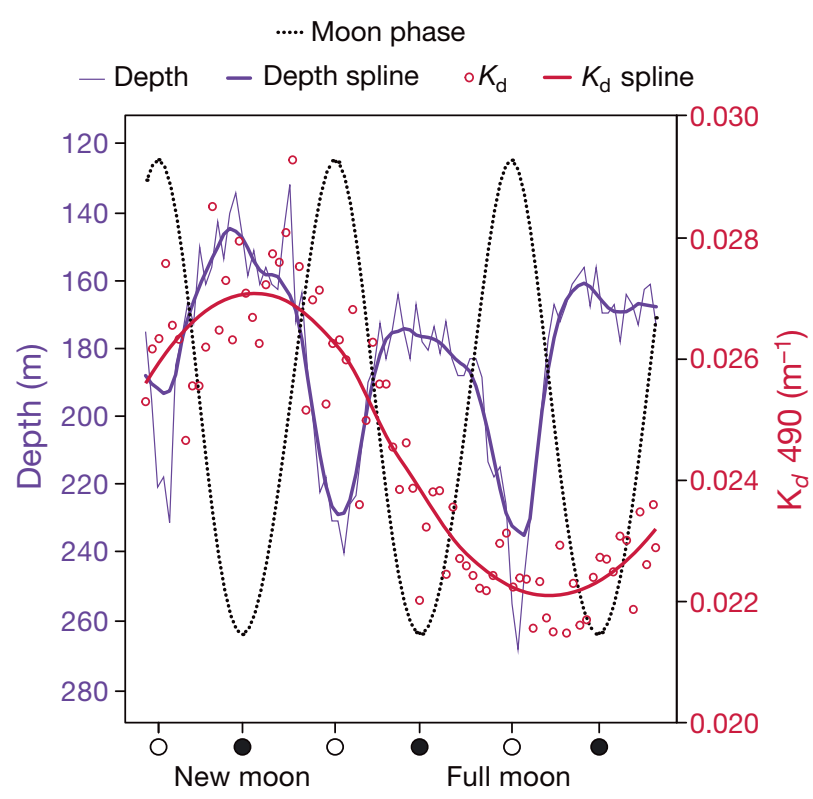

Fig. 4. Anguilla marmorata. Moon phase (dotted black line), night-time upper migration depths (daily median: thin blue; spline curve: bold blue), and spectral irradiance at $490 \mathrm{~nm}$ (daily $K_{\mathrm{d}}$ estimates: red dots; spline curve: bold red) along a straight line between release and pop-up location

$165 \mathrm{~km}$ from the point of release, after it surfaced $5 \mathrm{~d}$ prior to the scheduled pop-up day.

\section{Anguilla megastoma, Eel 4}

This eel also exhibited a distinct DVM behaviour from the beginning, with a gradual increase in migration depth (Fig. 2C). After $6 \mathrm{~d}$ it descended to $980 \mathrm{~m}$ for $2 \mathrm{~d}$. It resumed a vertical migration similar to Eel 3 between median depths of $670 \mathrm{~m}$ (640 to $699 \mathrm{~m}$ ) during the day and $299 \mathrm{~m}$ (285 to $323 \mathrm{~m}$ ) during the night, experiencing temperatures of $11.4^{\circ} \mathrm{C}$ $\left(10.4\right.$ to $\left.12.0^{\circ} \mathrm{C}\right)$ and $15.3^{\circ} \mathrm{C}\left(13.7\right.$ to $\left.15.7^{\circ} \mathrm{C}\right)$. The tag surfaced prematurely after $35 \mathrm{~d}, 16 \mathrm{~km}$ west of Gaua.

\section{Anguilla obscura, Eel 6}

After release, this eel dove to $530 \mathrm{~m}$ and then exhibited DVM, though less pronounced than in its congeners, between median depths of $312 \mathrm{~m}$ (264 to $371 \mathrm{~m}$ ) during the day and $226 \mathrm{~m}$ (204 to $258 \mathrm{~m}$ ) during the night, corresponding to $15.1^{\circ} \mathrm{C}(12.1$ to $16.8^{\circ} \mathrm{C}$ ) and $19.7^{\circ} \mathrm{C}\left(17.9\right.$ to $\left.20.5^{\circ} \mathrm{C}\right)$ (Fig. 2D). The tag stayed on the eel for almost 3 mo and then surfaced $1 \mathrm{wk}$ before the programmed pop-off date $43 \mathrm{~km}$ north-west of the point of release.

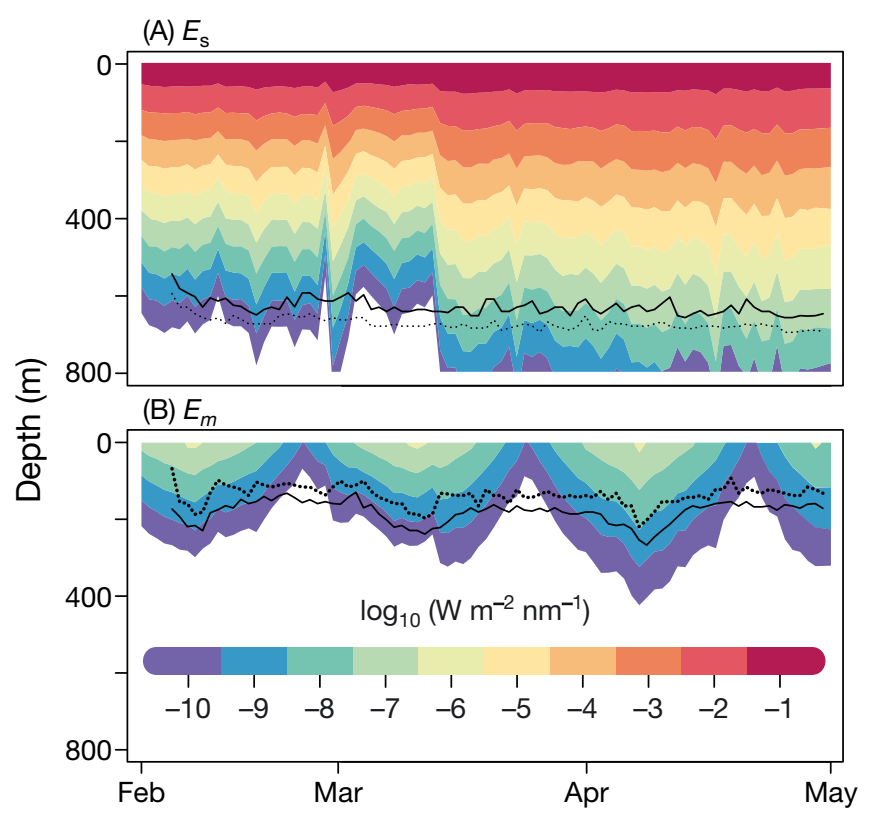

Fig. 5. Anguilla marmorata. Spectral irradiance at $490 \mathrm{~nm}$ versus depth for $(\mathrm{A})$ sunlight $\left(E_{\mathrm{s}}\right)$ and $(\mathrm{B})$ moonlight $\left(E_{\mathrm{m}}\right)$, assuming migration with constant speed and along a straight line between release and pop-up location. Solid lines correspond to median migration depths during (A) day and (B) night, and dotted lines correspond to (A) maximum daytime and (B) minimum night-time migration depths

\section{Anguilla obscura, Eel 7}

For $1 \mathrm{wk}$, the eel showed irregular swimming activity between the surface and $150 \mathrm{~m}$ depth, frequently moving up and down every day. The fish could have been preyed upon shortly after release. After $16 \mathrm{~d}$ at the surface it descended for $4 \mathrm{~d}$ to $400 \mathrm{~m}$ depth. It started transmitting on 9 March 2012 south of Esperitu Santo, Vanuatu.

\section{DISCUSSION}

\section{Tropical eels on Gaua Island}

At least 3 species of tropical eels occur sympatrically in the outflow of Lake Letas. Anguilla marmorata and A. megastoma dominated the catch, but A. obscura was discovered in the lower stretches of Mbe Solomul River. The latter species remained undetected in a previous survey (Keith et al. 2011), during which $A$. reinhardtii was caught in rivers on the neighbouring islands of Vanua Lava and Maewo, and, hence, may be present as a fourth species. Only A. marmorata and A. megastoma seem to colonize Lake Letas by surmounting the $120 \mathrm{~m}$ high Siri Falls. Both species are 

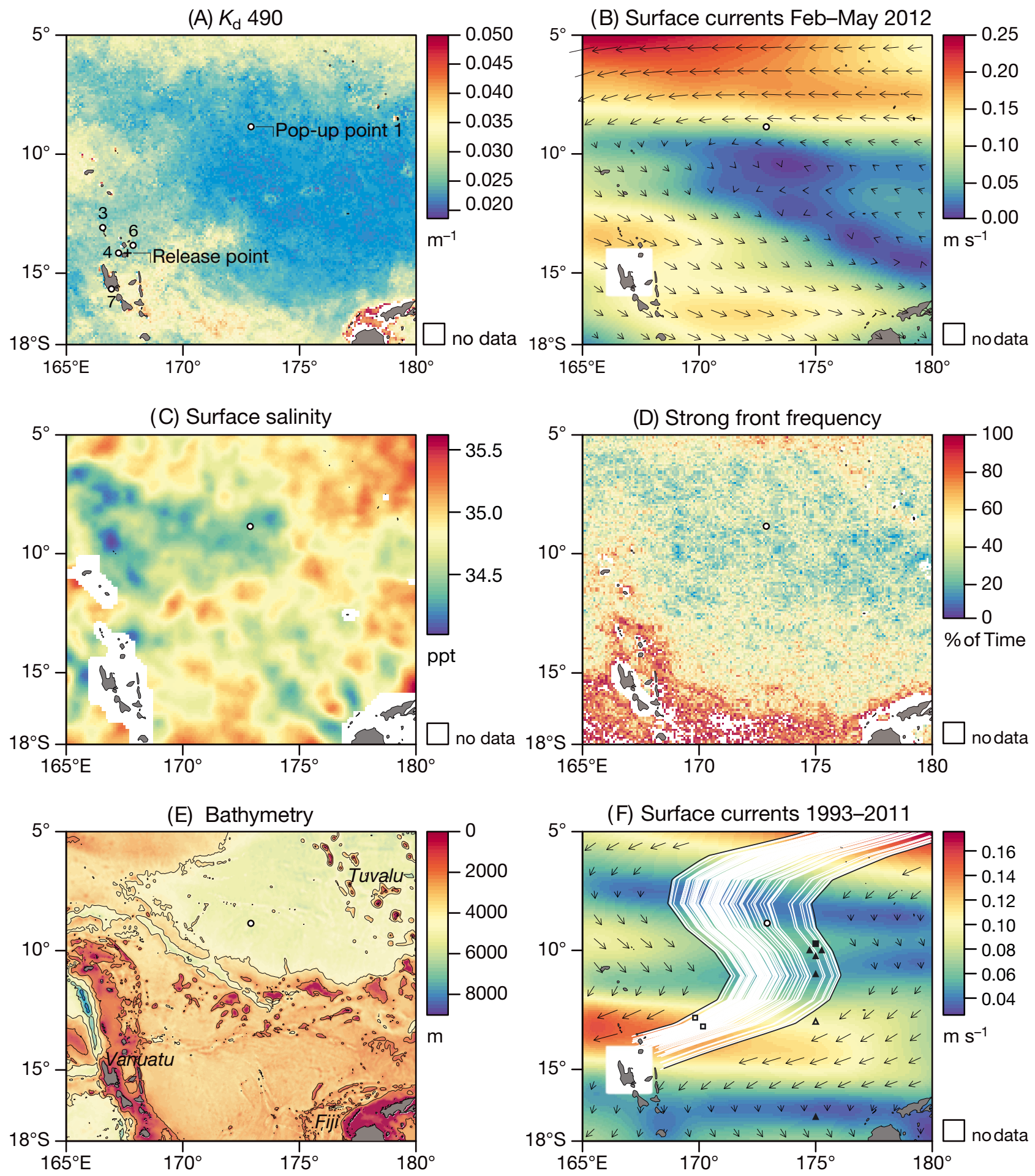

Fig. 6. Anguilla marmorata, A. megastoma. Maps of (A) vertical attenuation coefficient $K_{\mathrm{d}}$ (numbered circles correspond to PSAT pop-up locations), (B) surface currents, (C) surface salinity, (D) frequency of thermal fronts, (E) bathymetry, and (F) simulated backward drift trajectories of 100 points released near Gaua under average flow regimes. Panels A, B, and C are temporal averages for February to May 2012, and Panel D for February to May 2006-2011. Positions where leptocephali of A. marmorata (triangles) and A. megastoma (squares) have been collected and identified either morphologically (open squares and triangles) or genetically (filled squares and triangles; Kuroki et al. 2008 and references therein) are shown in comparison to the pop-up location of the A. marmorata tag (open circle). For details see 'Materials and methods' 
known from the upper stretches of running waters on South Pacific islands (Marquet \& Galzin 1991, Marquet 1996). Elvers must surmount the cataract through the mossy cliffs flanking the river, while the adult silver eels plummet down the falls.

The large, deep, and productive lake and its outflowing river offer favourable feeding conditions. Maximum body sizes of eels exceeded those reported from New Caledonia (Marquet 1996). To our knowledge, we caught the largest Anguilla obscura ever reported. This facilitates tagging experiments, because negative effects of externally attached transmitters on swimming performance should be reduced in large, well-nourished fish (Burgerhout et al. 2011, Methling et al. 2011).

The majority of Lake Letas eels appear to commence their downward migration during the wet season, between January and March. Our preliminary observations confirmed reports from local fishermen that silver eels of both species aggregate in the pool below Siri Falls after heavy rains, but the eels probably then need an unknown amount of time in the lowest stretches of the river to complete their silvering process before going out to sea. As Anguilla marmorata was caught next to the mouth of the river, it could have been the only fish that was about to leave freshwater. In tropical eels, the time frame for the entrance into the sea may be less restricted than in temperate species (Miller et al. 2002, Jellyman 2003).

We were unable to assure that tagged fish were physiologically fully ready to begin their oceanic spawning migration. Silvery colour, enlarged eyes, capture in the flooding river, and presumably empty stomachs were strong indicators, but the seemingly random pop-up locations near Gaua of all but 1 tag show that departure may not have been imminent. Additionally, capture, tagging, and offshore release could have disoriented them.

\section{Diel vertical migration}

Once released into the ocean, all 3 species of tropical Pacific eels exhibited DVMs similar to temperate species. For Anguilla marmorata and A. megastoma these exceeded $500 \mathrm{~m}$ in amplitude, while A. obscura exhibited a smaller range of 100 to $200 \mathrm{~m}$. Except for one A. obscura that probably died after a week, all species avoided the top $100 \mathrm{~m}$ of the water column during the night and steeply descended to depths beyond $300 \mathrm{~m}$ at dawn. Hence, this behaviour must be strongly adaptive.
We hypothesize that predator avoidance is an important factor driving this pronounced DVM behaviour in tropical eels (Jellyman \& Tsukamoto 2002). There is strong evidence for predation on eels entering the ocean (Béguer-Pon et al. 2012). Upon release, all our eels were observed to plunge down. Avoidance of visually oriented predators is important for a fish that has limited escape abilities and migrates in the open ocean for several months. Information on diving behaviour accumulating from tagging studies of potential pelagic fish predators in the Pacific, such as various species of sharks (Stevens et al. 2010, Musyl et al. 2011), swordfish Xiphias gladius (Dewar et al. 2011), and large tuna (Musyl et al. 2003, Schaefer et al. 2007), shows that eels descending beyond 500 and $200 \mathrm{~m}$ during day and moon-lit nights, respectively, could significantly reduce their risk of predation. These migration depths do not conceal them from toothed whales (Aoki et al. 2007, Baird et al. 2008), but these predators predominantly target larger prey aggregations by echolocation (Evans \& Hindell 2004). As there is no evidence that eels migrate in large shoals, they are probably not a primary target. However, there is indication of occasional whale predation on European eels (K. Aarestrup pers. obs.). Losses to deep-living foragers (sharks, squid, etc.) may be less than to the more abundant epipelagic predatory fish (Priede et al. 2006).

The distinct lunar cycles reflected in the upper limits of migration depths in Anguilla marmorata support the hypothesis that predator avoidance is an important driving force behind these vertical migrations. Of 6 American eels A. rostrata preyed upon by sharks, 4 were eaten during daytime and 2 at full moon (Béguer-Pon et al. 2012). A positive correlation between night-time depth and lunar illumination was found in pelagic predators such as bigeye tuna Thunnus obesus (Musyl et al. 2003), swordfish (Dewar et al. 2011), and several species of sharks (Campana et al. 2011, Musyl et al. 2011). During full moon, blue sharks dive 3 times deeper $(>100 \mathrm{~m})$ than during new moon (Campana et al. 2011), and swordfish increase mean night-time depth to $70-220 \mathrm{~m}$ (Dewar et al. 2011). Extended foraging depths of these apex predators during well-lit nights are the most plausible explanation. Hence, avoiding the epipelagic layers at this time may be vital to hide from nocturnally foraging predators.

Anguilla marmorata did not entirely follow an isolume up and down the water column, as light levels changed along its assumed migration path, and it was probably exposed to higher irradiance during the day than that it was trying to avoid during full 
moon. With $5^{\circ} \mathrm{C}$ at maximum depth, it probably approaches its physiological limit for movement (Vollestad \& Jonsson 1986), although European eels have been found moving at lower temperatures (K. Aarestrup pers. obs.). Why the eels avoided the top $150 \mathrm{~m}$ even during dark new moon nights remains unknown. Higher densities of predators (Priede et al. 2006), which also rely on olfactory stimuli to locate prey in warmer and faster-moving surface waters, may render the upper epipelagic zone too dangerous for migrating eels. They may have been hiding, deeper down, below certain irradiance levels. Spectral sensitivities under scotopic conditions in eels (Archer et al. 1995) and potential predators (Matsumoto et al. 2009, McComb et al. 2010) are similar at wavelengths where light penetration is maximal in open water (i.e. $490 \mathrm{~nm}$ ). Tags with higher light sensitivity are needed to test if eels regulate their migration depth according to ambient light levels, although at the moment this is technically unfeasible.

We hypothesize that migrating eels adjust their depth in order to minimize encounters with the majority of visually oriented predators by diving from epipelagic to mesopelagic layers during dawn. A human observer looking horizontally in clearest ocean water could still detect sun- and moonlight at 750 and $300 \mathrm{~m}$ depth, respectively (Clarke \& Denton 1962, Denton 1990). Eels and their predators, with large eyes and higher spectral sensitivities, can probably use visual cues 100 to $200 \mathrm{~m}$ deeper. However, the angular elevations of sun and moon, clouds, absorption, and scattering of light in waters of varying turbidity could move these thresholds to shallower depths.

The ascent into shallow, warmer water is probably necessary to maintain a sufficiently high metabolism. Moderately warm temperatures $>18^{\circ} \mathrm{C}$ seem to be optimal for swimming performance (Haro 1991, Van Ginneken \& Maes 2005) and gonad maturation (Sato et al. 2006) of temperate eels and should be even more important in tropical species. By steep ascents during dusk, the eels could maximize the sojourn to favourable conditions. On the other hand, the daytime temperatures at great depth $\left(5\right.$ to $\left.6^{\circ} \mathrm{C}\right)$ are considered too cold for continuous swimming (Jellyman \& Tsukamoto 2005). Hence, the distinct DVM in tropical eels could be governed by the principle: 'hide, but warm up'. Nevertheless, other factors could be superimposed.

Besides predator avoidance, behavioural thermoregulation to retard gonadal development is currently thought to explain these regular and extended dives into cold water. Jellyman \& Tsukamoto (2010) argue that ripening females may thereby be able to keep the drag of their growing abdomen low until just before arrival at the spawning areas. According to this line of reasoning, vertically migrating tropical eels should then also exhibit long-distance migrations. However, maturation control alone is unlikely to explain the fast and daily descents below $10^{\circ} \mathrm{C}$. Anguilla marmorata experienced changes in temperature of $>17^{\circ} \mathrm{C}$ within $2 \mathrm{~h}$, a remarkable change for a poikilothermic animal. During steep descents, temperature changes even exceeded the technical limit of transmitting delta-delimited values. While cool temperatures and high pressure may indeed be required for maturation control and optimal metabolism (Sébert et al. 2009), the rapid dives into water far below the eel's thermal optima (Tesch 2003) seem to be governed by predator avoidance, since, otherwise, they could reside in intermediate depth ranges or perform moderate DVM.

Other evolutionary forces could have been selective for this behaviour, but, at the current state of knowledge, seem less plausible to explain DVM in tropical Pacific eels. Constantly dim light and highly fluctuating temperatures may be necessary for photothermal control of gonad maturation (Wang et al. 2010). Vertical ascents into epipelagic layers in order to increase the probability of locating oceanic fronts and olfactory cues from conspecifics may be important when approaching the spawning site, but come at a seemingly unnecessary energetic cost at the onset of a several month long oceanic migration. Eels seem to migrate too deeply for celestial navigation by sun-, moon-, or starlight (Jellyman \& Tsukamoto 2010). As geomagnetic information does not increase with depth, eels do not need to descend for orientation (Jellyman \& Tsukamoto 2005). Vertical migration is unlikely in order to assist transport in favourable currents, because the behaviour is strikingly similar in temperate and tropical eels exposed to contrasting environmental conditions. At the northern edge of the archipelago of Vanuatu ocean currents are complex, with a strong influence of topography and pronounced seasonal variability (Ganachaud et al. 2007). The tagged Anguilla marmorata crossed different current systems, but still retained its regular vertical migration pattern.

It remains unknown why 1 Anguilla obscura died early and the other specimen exhibited a more irregular DVM pattern, with a smaller amplitude in comparison to the other species. The 2 eels could have been resident fish in the river that were less ready to go to sea. Unlike its congeners, A. obscura has a silvery appearance throughout its life (Keith et al. 
2011), but sample size was too small for comparison of resident and migrating fish. However, it can be excluded that Fish 6 was eaten by a predator, as the tag recorded data for almost the programmed 3 mo and would have passed the digestive system much faster.

\section{Spawning migration}

The exact numbers of spawning populations of tropical eels across the Pacific are not yet known. Based on morphological analyses (Watanabe et al. 2011, 2012), it is hypothesized that there are 3 populations of Anguilla marmorata (North Pacific, Micronesia, South Pacific), 2 of A. megastoma (West and East Pacific), and 1 panmictic population of $A$. obscura. Molecular studies have confirmed at least 3 stocks of A. marmorata (Ishikawa et al. 2004, Minegishi et al. 2008).

The spawning areas for the 3 species have been postulated to lie within the SEC (Jellyman 2003). The current may extend beyond $400 \mathrm{~m}$ depth (Miller et al. 2006). West of Gaua the SEC has a 2-core structure, with a southern (ca. 10 to $18^{\circ} \mathrm{S}$ ) and a northern westward branch (ca. 0 to $5^{\circ} \mathrm{S}$ ), separated by the southeastward flow of the South Equatorial Counter Current (SECC, ca. 5 to $10^{\circ} \mathrm{S}$ ). There is a strong seasonal and inter-annual variability in latitudinal positions and flow rates coupled to El Niño-Southern Oscillation (ENSO) events (Reverdin et al. 1994, Ganachaud et al. 2007) (Fig. 6B,F). The strength of the SECC normally increases during and after the rainy season in March, while the westward flow of the SEC towards Vanuatu increases between May and October (OSCAR; Chen \& Qiu 2004), potentially facilitating adult eastward migration and westward larval drift.

Only a few leptocephali of these tropical eels have ever been collected in the western South Pacific, predominantly from 2 to $20^{\circ} \mathrm{S}, 155$ to $175^{\circ} \mathrm{E}$ (Kuroki et al. 2008 and references therein). Anguilla marmorata headed towards the equator-near branch of the SEC, and the tag surfaced only 255 to $330 \mathrm{~km}$ north-west of the points $\left(10\right.$ and $\left.11^{\circ} \mathrm{S}, 175^{\circ} \mathrm{E}\right)$ where 4 small leptocephali of this species had previously been captured (19 to $36.8 \mathrm{~mm}$ total length, 25 to $155 \mathrm{~d}$ old; Fig. 6F), with the smallest larva ever caught to date among them. Assuming that the larvae drift with the SEC at a maximum speed of $0.15 \mathrm{~m} \mathrm{~s}^{-1}$, the spawning area is likely located somewhere near the Tuvalu archipelago.

We can only speculate about the spawning areas of Anguilla megastoma and A. obscura. With the pop- up of tags within the Vanuatu archipelago, nearby offshore spawning cannot be ruled out, but to date there is no evidence for the existence of several local stocks across their wide distribution ranges (Watanabe et al. 2011, 2012). Three of the 4 A. megastoma leptocephali ever collected to date were found northeast of Vanuatu $\left(10\right.$ to $13^{\circ} \mathrm{S}, 170$ to $175^{\circ} \mathrm{E}$; Kuroki et al. 2008) (Fig. 6F), showing that sympatric A. megastoma and $A$. marmorata from Gaua could theoretically be using similar migration routes to the same oceanographic features for spawning. To date, only 3 A. obscura larvae have been found, 2 south-west of Vanuatu and 1 south of Fiji. For both species further information is needed before even coarse limits can be set for the search area.

Hydrographic fronts are key features of eel spawning areas (Kleckner \& McCleave 1988, Tsukamoto et al. 2011). For tropical Pacific eels they may be located at the southern edge of the West Pacific fresh pool north or north-west of Fiji (Miller et al. 2009), a lens of relatively low salinity water that results from a net freshwater input in the western tropical Pacific (Fig. 6C). Variable salinity fronts are observed, where they slide over central Pacific surface waters (Hénin et al. 1998). Should seamounts be important additional landmarks for spawning, as proposed for Anguilla japonica and A. marmorata near the Mariana Ridge (Tsukamoto et al. 2011), temperature fronts forming west and north of Tuvalu may be promising targets to search for leptocephali. This area is littered with geologically old seamounts (30 to 70 million yr old, Koppers et al. 2001, A. Koppers pers. comm.), and eels may have evolved to use these structures as landmarks for their spawning areas.

Consequently, the time needed to reach the spawning areas remains unknown. Average migration speeds of similar-sized Anguilla dieffenbachii (Jellyman \& Tsukamoto 2010) exceeded those of the single tagged $A$. marmorata by almost 3-fold. In fact, we cannot exclude that the latter had already been close to the spawning area and had still retained its regular DVM behaviour, although movement to shallower water is thought to be necessary for final maturation (Palstra et al. 2009). Should spawning occur further east, the total duration may be in the range of 4 to $5 \mathrm{mo}$.

We also do not know if there is a distinct spawning season for these eels from Vanuatu. Near the Marianas, Anguilla marmorata seems to spawn throughout much of the year (Miller et al. 2002). Glass eel recruitment within the archipelago has been observed between October and April for A. marmorata and between April and July for A. megastoma and $A$. 
obscura (Keith et al. 2011), implying that the different species may have a different timing in their reproductive cycles and/or different spawning areas.

Further tagging studies of adult eels and surveys of leptocephali are needed to narrow down the search for spawning areas of Pacific eels. With decreasing supplies of temperate eels, pressure on tropical species will increase. By then, information on their life cycles, stock structures, and survival rates are crucial for effective management.

Acknowledgements. This publication is dedicated to the memory of the late Professor 'Onkel Hans' Adam, who was a continuous source of inspiration to the first author. Field work was carried out under a permit (30/12/2011) and in concordance with the code of ethics for foreign researchers from the Government of Vanuatu. This study was funded through a grant from the International Programs of the Austrian Academy of Sciences. Satellite time and transmitters for refurbishment were provided by Grant 212133 'Eeliad' (European Union, FP7). Salaries for R.S. and F.Ø. during the field operation were covered by their institutions. R. Brodeur, D. Jellyman, D. Righton, and 3 anonymous reviewers provided numerous constructive comments. A. Williams, Director of the Department of Environmental Protection and Conservation, supported our field operations. We thank the staff of Wildlife Computers and Microwave Telemetry for technical advice. This work would not have been possible without the community on Gaua. We are grateful to Chiefs V. Wotias and P. Lazarus as representatives for all who have helped us.

\section{LITERATURE CITED}

Aarestrup K, Økland F, Hansen MM, Righton D and others (2009) Oceanic spawning migration of the European eel (Anguilla anguilla). Science 325:1660

Alerstam T, Hedenström A, Åkesson S (2003) Long-distance migration: evolution and determinants. Oikos 103: $247-260$

> Aoki K, Amano M, Yoshioka M, Mori K, Tokuda D, Miyazaki N (2007) Diel diving behaviour of sperm whales off Japan. Mar Ecol Prog Ser 349:277-287

Aoyama J (2009) Life history and evolution of migration in catadromous eels (genus Anguilla). Aqua BioSci Monogr $2: 1-42$

Aoyama J, Wouthuyzen S, Miller MJ, Inagaki T, Tsukamoto K (2003) Short-distance spawning migration of tropical freshwater eels. Biol Bull 204:104-108

> Archer S, Hope A, Partridge JC (1995) The molecular basis for the green-blue sensitivity shift in the rod visual pigments of the European eel. Proc Biol Sci 262:289-295

Baird RW, Webster DL, Schorr GS, McSweeny DJ, Barlow J (2008) Diel variation in beaked whale diving behaviour. Mar Mamm Sci 24:630-642

Béguer-Pon M, Benchetrit J, Castonguay M, Aarestrup K, Campana SE, Stokesbury MJW, Dodson JJ (2012) Shark predation on migrating adult American eels (Anguilla rostrata) in the Gulf of St. Lawrence. PLoS ONE 7:e46830

Burgerhout E, Manabe R, Brittijn SA, Aoyama J, Tsukamoto
K, Van den Thillart G (2011) Dramatic effect of pop-up satellite tags on eel swimming. Naturwissenschaften 98: 631-634

> Campana SE, Dorey A, Fowler M, Joyce W, Wang Z, Wright D, Yashayaev I (2011) Migration pathways, behavioural thermoregulation and overwintering grounds of blue sharks in the Northwest Atlantic. PLoS ONE 6:e16854

- Chen S, Qiu B (2004) Seasonal variability of the South Equatorial Countercurrent. J Geophys Res 109:C08003, doi: 10.1029/2003JC002243

Chow S, Kurogi H, Mochioka N, Kaji S, Okazaki M, Tsukamoto K (2009) Discovery of mature freshwater eels in the open ocean. Fish Sci 75:257-259

Clarke GL, Denton EJ (1962) Light and animal life. In: Hill MN (ed) The sea, Vol 1. New Interscience Publishers, New York, NY, p 456-468

Denton EJ (1990) Light and vision at depths greater than 200 metres. In: Herring PJ, Campbell AK, Whitefield M, Maddock L (eds) Light and life in the sea. Cambridge University Press, Cambridge, p 127-148

Dewar H, Prince ED, Musyl MK, Brill RW and others (2011) Movements and behaviours of swordfish in the Atlantic and Pacific Oceans examined using pop-up satellite archival tags. Fish Oceanogr 20:219-241

Ege V (1939) A revision of the genus Anguilla Shaw. Reports of the Dana expedition 16, Copenhagen, p 248-251

- Evans K, Hindell MA (2004) The diet of sperm whales (Physeter macrocephalus) in southern Australian waters. ICES J Mar Sci 61:1313-1329

> Friedland K, Miller MJ, Knights B (2007) Oceanic changes in the Sargasso Sea and declines in recruitment of the European eel. ICES J Mar Sci 64:519-530

Ganachaud A, Kessler W, Wijffels S, Ridgway K and others (2007) Southwest Pacific Ocean Circulation and Climate Experiment (SPICE). Part I. Scientific background. International CLIVAR Project Office, CLIVAR Publication Series No. 111, NOAA OAR Special Report, NOAA/ OAR/PMEL, Seattle, WA

Gregg WW, Carder KL (1990) A simple spectral solar irradiance model for cloudless maritime atmospheres. Limnol Oceanogr 35:1657-1675

Haenen OLM, Van Ginneken VJT, Engelsma M, Van den Thillart G (2009) Impact of eel viruses on recruitment of European eel. In: Van den Thillart G, Dufour S, Rankin JC (eds) Spawning migration of the European eel: reproduction index, a useful tool for conservation management. Fish \& Fisheries Series 30, Springer Netherlands, London, p 387-400

Haro AJ (1991) Thermal preferenda and behaviour of Atlantic eels (genus Anguilla) in relation to their spawning migration. Environ Biol Fishes 31:171-184

Hénin CJ, du Penhoat Y, Ioualalen M (1998) Observations of the sea surface salinity in the western Pacific fresh pool large scale changes in 1992-1995. J Geophys Res 103: 7523-7536

Ishikawa S, Tsukamoto K, Nishida M (2004) Genetic evidence for multiple geographic populations of the giant mottled eel Anguilla marmorata in the Pacific and Indian Oceans. Ichthyol Res 51:343-353

Jellyman D (1991) Biology of the shortfinned eel Anguilla obscura in Lake Te Rotonui, Mitiaro, Cook Islands. Pac Sci 45:362-373

Jellyman DJ (2003) The distribution and biology of the South Pacific species of Anguilla. In: Aida K, Tsukamoto K, Yamauchi K (eds) Eel biology. Springer, Tokyo, p 275-292 
Jellyman DJ, Tsukamoto K (2002) First use of archival transmitters to track migrating freshwater eels Anguilla dieffenbachii at sea. Mar Ecol Prog Ser 233:207-215

Jellyman DJ, Tsukamoto K (2005) Swimming depths of offshore migrating longfin eels Anguilla dieffenbachii. Mar Ecol Prog Ser 286:261-267

> Jellyman DJ, Tsukamoto K (2010) Vertical migrations may control maturation in migrating female Anguilla dieffenbachii. Mar Ecol Prog Ser 404:241-247

Keith P, Marquet G, Lord C, Kalfatak D, Vigneux E (2011) Vanuatu freshwater fish and crustaceans. Societé Française d'ichtthyologie, Paris

> Kieffer HH, Stone TC (2005) The spectral irradiance of the moon. Astron J 129:2887-2901

> Kleckner RC, McCleave JD (1988) The northern limit of spawning by Atlantic eels (Anguilla spp.) in the Sargasso Sea in relation to thermal fronts and surface water masses. J Mar Res 46:647-667

Knights B (2003) A review of the possible impacts of longterm oceanic and climate changes and fishing mortality on recruitment of anguillid eels of the Northern Hemisphere. Sci Total Environ 310:237-244

> Koppers AAP, Morgan JP, Morgan JW, Staudigel H (2001) Testing the fixed hotspot hypothesis using ${ }^{40} \mathrm{Ar} /{ }^{39} \mathrm{Ar}$ age progression along seamount trails. Earth Planet Sci Lett 185:237-252

Kuroki M, Aoyama J, Miller MJ, Watanabe S and others (2008) Distribution and early life-history characteristics of anguillid leptocephali in the western South Pacific. Aust J Mar Freshw Res 59:1035-1047

Kuroki M, Aoyama J, Miller M, Yoshinaga T, Shinoda A, Hagihara S, Tsukamoto K (2009) Sympatric spawning of Anguilla marmorata and Anguilla japonica in the western North Pacific. J Fish Biol 74:1853-1865

Manabe R, Aoyama J, Watanabe K, Kawai M, Miller MJ, Tuskamoto K (2011) First observations of the oceanic migration of Japanese eel, from pop-up archival transmitting tags. Mar Ecol Prog Ser 437:229-240

Marquet G (1996) The freshwater eels (Anguillidae) of New Caledonia: taxonomy and distribution. Vie Milieu 46: $65-71$

Marquet G, Galzin R (1991) The eels of French Polynesia: taxonomy, distribution and biomass. Mer (Paris) 29:8-17

Marquet G, Lamarque P (1986) Acquisitions récentes sur la biologie des anguilles de Tahiti et de Moorea (Polynésie Française): A. marmorata, A. megastoma, A. obscura. Vie Milieu 36:311-335

> Matsumoto T, Ihara H, Ishida Y, Okada T, Kurata M, Sawada Y, Ishibashi Y (2009) Electroretinographic analysis of night vision in juvenile Pacific bluefin tuna (Thunnus orientalis). Biol Bull 217:142-150

McComb DM, Frank TM, Hueter RE, Kajiur SM (2010) Temporal resolution and spectral sensitivity of the visual system of three coastal shark species from different light environments. Physiol Biochem Zool 83:299-307

> Methling C, Tudorache C, Skov PV, Steffensen JF (2011) Pop-up satellite tags impair swimming performance and energetics of the European eel (Anguilla anguilla). PLoS ONE 6:e20797

Miller P (2009) Composite front maps for improved visibility of dynamic sea-surface features on cloudy SeaWiFS and AVHRR data. J Mar Syst 78:327-336

Miller MJ, Mochioka N, Otake T, Tsukamoto K (2002) Evidence of a spawning area of Anguilla marmorata in the western North Pacific. Mar Biol 140:809-814
Miller MJ, Aoyama J, Mochioka N, Otake T and others (2006) Geographic variation in the assemblages of leptocephali in the western South Pacific. Deep-Sea Res 53: 776-794

Miller MJ, Kimura S, Frieland KD, Knights B, Kim H, Jellyman DJ, Tsukamoto K (2009) Review of ocean-atmospheric factors in the Atlantic and Pacific Oceans influencing spawning and recruitment of anguillid eels. Am Fish Soc Symp 69:231-249

Minegishi Y, Aoyama J, Tsukamoto K (2008) Multiple population structure of the giant mottled eel Anguilla marmorata. Mol Ecol 17:3109-3122

Munk P, Hansen MM, Maes GE, Nielsen TG and others (2010) Oceanic fronts in the Sargasso Sea control the early life and drift of Atlantic eels. Proc Biol Sci 277: 3593-3599

> Musyl MK, Brill RW, Boggs CH, Curran DS, Kazama TS, Seki MP (2003) Vertical movements of bigeye tuna (Thunnus obesus) associated with islands, buoys, and seamounts near the main Hawaiian Islands from archival tagging data. Fish Oceanogr 12:152-169

Musyl MK, Brill RW, Curran DS, Fragoso NM and others (2011) Postrelease survival, vertical and horizontal movements, and thermal habitats of five species of pelagic sharks in the central Pacific Ocean. Fish Bull 109: 341-368

Okamura A, Yamada Y, Yakouchi K, Horie N and others (2007) A silvering index for the Japanese eel Anguilla japonica. Environ Biol Fishes 80:77-89

Palstra A, Van Ginneken VJT, Van den Thillart G (2009) Effects of swimming on silvering and maturation of the European eel, Anguilla anguilla L. In: Van den Thillart G, Dufour S, Rankin JC (eds) Spawning migration of the European eel: reproduction index, a useful tool for conservation management. Fish \& Fisheries Series 30, Springer Netherlands, London, p 229-251

Priede IG, Froese R, Bailey DM, Bergstad OA and others (2006) The absence of sharks from abyssal regions of the world oceans. Proc Biol Sci 273:1435-1441

Reverdin G, Frankignoul E, Kestenare E, McPhaden MJ (1994) Seasonal variability in the surface currents of the equatorial Pacific. J Geophys Res 99:20323-20344

> Righton D, Aarestrup K, Jellyman D, Sébert P, Van den Thillart G, Tsukamoto K (2012) The Anguilla spp. migration problem: 40 million years of evolution and two millennia of speculation. J Fish Biol 81:365-386

> Sato N, Kawazoe I, Suzuki Y, Aida K (2006) Effects of temperature on vitellogenesis in Japanese eel Anguilla japonica. Fish Sci 72:961-966

> Schabetsberger R, Drozdowski G, Rott E, Lenzenweger R and others (2009) Losing the bounty? Investigating species richness in isolated freshwater ecosystems of Oceania. Pac Sci 63:153-179

Schaefer KM, Fuller DW, Block BA (2007) Movements, behavior, and habitat utilization of yellowfin tuna (Thunnus albacares) in the northeastern Pacific Ocean, ascertained through archival tag data. Mar Biol 152:503-525

Schmidt J (1922) The breeding places of the eel. Philos Trans R Soc Lond B Biol Sci 211:179-208

Schmidt J (1925) The breeding places of the eel. Ann Rep Smithson Inst 1924:279-316

Sébert P, Scaion D, Belhomme M (2009) High hydrostatic pressure improves the swimming efficiency of European migrating silver eel. Respir Physiol Neurobiol 165: 112-114 
Stevens JD, Bradford RW, West GJ (2010) Satellite tagging of blue sharks (Prionace glauca) and other pelagic sharks off eastern Australia: depth behaviour, temperature experience and movements. Mar Biol 157:575-591

Székely C, Palstra A, Molnár K, Van den Thillart G (2009) Impact of swim-bladder parasite on the health and performance of European eels. In: Van den Thillart G, Dufour S, Rankin JC (eds) Spawning migration of the European eel: reproduction index, a useful tool for conservation management. Fish \& Fisheries Series 30, Springer Netherlands, London, p 201-226

Tesch FW (1974) Speed and direction of silver and yellow eels, Anguilla anguilla, released and tracked in the open North Sea. Meeresforschung/Rep Mar Res 23:181-197

Tesch FW (2003) The eel, 3rd edn. Blackwell, Oxford

Tsukamoto K (2009) Oceanic migration and spawning of anguillid eels. J Fish Biol 74:1833-1852

Tsukamoto K, Chow S, Otake T, Kurogi H and others (2011) Oceanic spawning ecology of freshwater eels in the western North Pacific. Nature Commun 2: Article No. 179

Van den Thillart G, Palstra A, Van Ginneken VJT (2009) Energy requirements of European eel for transatlantic spawning migration. In: Van den Thillart G, Dufour S, Rankin JC (eds) Spawning migration of the European eel: reproduction index, a useful tool for conservation management. Fish \& Fisheries Series 30, Springer Netherlands, London, p 179-199

Editorial responsibility: Nicholas Tolimieri, Seattle, Washington, USA
Van Ginneken VJT, Maes GE (2005) The European eel (Anguilla anguilla, Linnaeus), its lifecycle, evolution and reproduction: a literature review. Rev Fish Biol Fish 15: 367-398

Van Ginneken VJT, Bruijs M, Murk T, Palstra A, Van den Thillart G (2009) The effect of PCBs on the spawning migration of European silver eel (Anguilla anguilla L.). In: Van den Thillart G, Dufour S, Rankin JC (eds) Spawning migration of the European eel: reproduction index, a useful tool for conservation management. Fish \& Fisheries Series 30, Springer Netherlands, London, p 365-386

- Vollestad LA, Jonsson B (1986) Life-history characteristics of the European eel Anguilla anguilla in the Imsa River, Norway. Trans Am Fish Soc 115:864-871

> Wang N, Teletchea F, Kestemont P, Milla S, Fontaine P (2010) Photothermal control of the reproductive cycle in temperate fishes. Rev Aquacult 2:209-222

Watanabe S, Miller MJ, Aoyama J, Tsukamoto K (2011) Analysis of vertebral counts of the tropical anguillids, Anguilla megastoma, A. obscura, and A. reinhardtii, in the western South Pacific in relation to their possible population structure and phylogeny. Environ Biol Fishes 91:353-360

Watanabe S, Miller MJ, Aoyama J, Tsukamoto K (2012) Evidence of population structure in five tropical eel species using total number of vertebrae. Proc World Fisheries Conference 2012, Fisheries Society of the British Isles, Edinburgh, p 125

Submitted: October 26, 2012; Accepted: January 8, 2013 Proofs received from author(s): February 2, 2013 